\title{
PENGAWASAN PEMERINTAH KOTA TERHADAP PENGELOLAAN SAMPAH KOTA PALANGKA RAYA
}

(Studi di Jalan Rajwali Kel. Bukit Tunggal, Kec. Jekan Raya, Kota Palangka

Raya)

\author{
Ajie Sepryadi
}

\begin{abstract}
ABSTRAK
Pengawasan terhadap pengelolaan sampah perlu dilakukan karena masalah sampah yang hingga kini di kota Palangka Raya belum dapat diselesaikan dan berpengaruh pada ikon kota. Hal demikian antara lain disebabkan oleh masih lemahnya pengawasan terhadap pengelolaan sampah yang dilakukan pemerintah kota melalui instansi tekait khususnya pada kawasan jalan Rajawali Kelurahan Bukit Tunggal Kecamatan Jekan Raya Kota Palangka Raya. Kondisi di kawasan tersebut ialah rendahnya tingkat kesadaran masyarakat untuk menjaga kebersihan lingkungan, TPS yang selalu dipenuhi sampah hingga di luar TPS, bau sampah yang menyengat hingga menganggu aktivitas warga yang tinggal di dekat TPS, dan angkutan sampah mengangkut sampah pada jam yang tidak menentu.

Tujuan penelitian ialah untuk mengetahui bentuk pengawasan terhadap pengelolaan sampah dan untuk mengetahui faktor pendukung dan faktor penghambat pengawasan terhadap pengelolaan sampah. Penelitian ini menggunakan metode kualitatif peneliti mengamati gejala yang terjadi di masyarakat dan memaparkannya seperti apa adanya tanpa diikuti persepsi peneliti. Kemudian dengan teknik pengumpulan data peneliti melakukan observasi, wawancara, dan melakukan dokumentasi. Berdasarkan hasil penelitian, bentuk pengawasan yang dilakukan terhadap pengelolaan sampah dengan melakukan absen secara manual kepada petugas angkutan sampah, penerapan sanksi kepada angkutan sampah yang melanggar aturan, dan pengawas bekerja sama dengan masyarakat melakukan pengawasan kinerja para petugas angkutan sampah. Faktor pendukung dari pengawasan ialah dengan absen manual kepada petugas angkutan sampah dan pengawas melakukan peninjauan kembali di tiap TPS, bekerja sama dengan masyarakat untuk mengawasi angkutan sampah. Faktor penghambat pengawasan ialah pengawasan langsung yang belum sepenuhnya terhadap petugas angkutan sampah dari awal angkutan sampah bekerja hingga akhir petugas angkutan sampah bekerja, belum adanya tindakan tegas dari pengawas terhadap masyarakat yang membuang sampah sembarangan untuk memberikan efek jera dan monitoring terhadap TPS yang rusak sehingga dapat diperbaiki.
\end{abstract}

Kata Kunci: PengawasanPemerintah Kota, PengelolaanSampah.

\begin{abstract}
Controlled for trash management need to be done because trash problem in Palangka Raya city until now could not solved yet and effected for city icon. Its thus is caused by weakness of controlled for trash management which is did by municipality through relevant institute especially in the area Rajawali Street, Bukit Tunggal village, Jekan Raya sub-district, Palangka Raya city. Condition in this area was lacked of awareness from society to keep environmental clean. TPS which is always filled trash and out from TPS, and trash transportation lifted trash on uncertain time.

The research was conducted to know conformation of control to trash management and to know supporting factors and obstacle factors control towards trash management. This research used qualitative method, the researcher observed phenomenon that occurred in society
\end{abstract}


and exposed as it is without followed by researcher's perception. Then with collecting data technique researcher was did observation, interview, and documentation.

Based on result of the research, conformation of control which is conducted for trash management with did absent manually to operator trash transportation, application of sanctions to trash transportation which is broke the rules, and controller cooperate with society to control performance of operator trash transportation. Supporting factors of controlling are with absent manually to operator trash transportation and controller survey in every TPS, cooperate with society to controlled trash transportation. Obstacle factors of controlling are directly control has not been fully for operator trash transportation from the beginning trash transportation worked until the and operator trash transportation has been work, yet decisive actions from controller to society which is threw trash littering to give wary effect and monitoring of TPS which is broken so could be fixed.

Keywords: Controlling of municipality, trash management.

\section{PENDAHULUAN}

\section{Latar Belakang}

Pengawasan dalam pengelolaan sampah merupakan faktor yang sangat penting untuk menunjang keberhasilan pemerintah kota dalam menjalankan salah satu tugasnya yaitu menjaga kebersihan kota. Berkaitan dengan program atau kebijakan yang akan dijalankan oleh suatu organisasi pemerintah untuk mengetahui sejauh mana implementasi kebijakan yang telah dibuat dan melakukan perbaikan-perbaikan terhadap kesalahan yang terjadi, sehingga dapat mencegah kesalahan untuk tidak kembali terjadi sehingga apa yang menjadi tujuan dari kebijakan akan terlaksana sesuai dengan rencana yang telah ditetapkan.

Karena itu pengawasan merupakan salah satu faktor keberhasilan pemerintah kota dalam mengatasi persoalan sampah yang hingga kini masih menjadi masalah yang sangat sukar untuk diselesaikan maka perlu ada pengawasan yang diilakukan pemerintah kota melalui instansi terkait yang memiliki tugas melaksanakan program-program yang telah dibuat pemerintah dalam penanggulangan masalah sampah yang hingga kini masih sulit di atasi karena berpengaruh terhadap ikon kota. Dimana masalah sampah merupakan masalah yang terjadi disetiap kota khususnya pada kota Palangka Raya yang melalui Dinas Pasar Dan Kebersihan Kota Palangka Raya pada Seksi Angkutan Sampah yang berfungsi sebagai pengelolaan sampah dan melakukan pengawasan terhadap pengelolaan sampah di jalan Rajawali masih dinilai kurang.

Pemerintah kota ingin mewujudkan kota yang bersih dengan berbagai kebijakan seperti program 3R (Reduce, Reuse, Recycle) dengan tujuannya yaitu mengurangi jumlah sampah adalah demi menjaga kelestarian lingkungan, tercipta lingkungan yang bersih dan sehat juga bisa meningkatkan tingkat kesejahteraan dengan hasil mengolah sampah serta sebagai sarana edukasi bagi semua akan pentingnya pengelolaan sampah. Namun, program ini masih mengalami kendala sehingga pelaksanaan tersebut masih belum berjalan dengan efektif karena terlihat dari kondisi kebersihan kota Palangka Raya yang masih terlihat minimdikarenakan kesadaran dari masyarakat terhadap kebersihan lingkungan dan kinerja dari sistem pengawasan yang masih terlihat minim dalam pengelolaan sampah khusus pada kawasan jalan Rajawali Kelurahan Bukit Tunggal Kecamatan Jekan Raya Kota Palangka Raya.

Seperti yang telah diuraikan sebelumnya, bahwa pemerintah kota melalui instansi terkait yang dalam hal ini ialah Dinas Pasar Dan KebersihanKota Palangka Raya dalam bentuk pengawasan terhadap pengelolaan sampah dikawasan jalan RajawaliKelurahan Bukit Tunggal Kecamatan Jekan Raya Kota Palangka Raya dengan menggunakan beberapa armada pengangkut sampah yang berfungsi mengangkut sampah pada TPS dan sampah yang 
berserakan di luar TPS yang dalam pengangkutan tersebut sesuai dengan jam yang telah ditetapkan oleh instansi pada bidang kebersihan serta dalam pengadaaan sarana prasarana terdapat beberapa TPSyang terlihat di jalan induk maupun di jalan komplek perumahan jalan Rajawali. Terlihat TPS tersebut masih belum bisa menampung sampah dengan maksimal karena kapasitas TPS tidak sebanding dengan jumlah volume sampah dari masyarakat yang semakin meningkat di jalan Rajawali serta masih banyak sampah yang menumpuk di TPS dan diluar atau berdekatan pada TPS yang masih terlihat mengotori pinggiran jalan dikawasan tersebut.

Jalan Rajawali merupakan kawasan yang padat penduduk tentu tidak lepas dari sampah pada setiap rumah masyarakat yang tinggal dikawasan tersebut.TPS merupakan faktor yang pendukung untuk kebersihan kawasan jalan Rajawali serta penempatan TPS harus tepat dan sebanding dengan jumlah sampah pada setiap masyarakat yang tinggal di kawasan tersebut. Namun, dilihat dari banyak sampah yang memenuhi TPS dan bahkan TPS yang tidak bisa menampung sampah sehingga sampah sering kali terlihat di luar dari TPS yang telah disediakan.

Selain itu, penyebab lain banyak sampah yang berserakan di luar TPS karena ada para pemulung sampah yang biasa memilah sampah di TPSdan dari petugas kebersihan sendiri dalam pengawasan masih dinilai kurang karena sampah yang berserakan di luar TPS ataupun di pinggir jalan masih terkesan tidak segera diangkut pada jadwal yang telah ditentukan. Padahal, TPS sudah terlihat penuh dan tidak sanggup lagi menampung banyak sampah berasal dari masyarakat yang tinggal di kawasan tersebut.

Kemudian penumpukan sampah disetiap TPS menjadi hal yang sudah biasa terjadi di kawasan jalan rajawali karena sampah yang sangat banyak pada pengangkutannya kadang terlihat mengalami keterlambatan sehingga menyebabkan penimbunan sampah dilokasi tersebut dan penyebab lain ialah juga disebabkan oleh tanpa ada penanganan dari warga setempat yang seharusnya berpartisipasi membuang sampah sesuai waktu yang ditentukan serta peran dari pemerintah kota melalui instansi terkait yang masih dinilai minim pada pengawasan di kawasan tersebut. Selain terdapat penumpukkan sampah tentu ada bau busuk yang menyengat akibat dari banyak sampah yang berserakan seperti sampah organik dan nonorganik. Kondisi-kondisi yang tidak nyaman tersebut sudah menjadi hal yang biasa bagi warga setempat yang tinggal di kawasan jalan Rajawali karena kebiasaan warga yang kurang memelihara kondisi lingkungan tempat tinggal mereka serta peran dari instansi terkait yang dalam kinerjanya masih belum maksimal.

Untuk mendorong partisipasi masyarakat dalam pengelolaan sampah di area tempat tinggal mereka sendiri masih mengalami kesulitan karena kesadaran masyarakat yang masih kurang dalam memelihara kebersihan, himbauan atau sosialisasi tentang kebersihan lingkungan yang hanya sampai pada tingkat kelurahan,dan ditambah kinerja dari pengawas yang belum terlihat maksimal terlihat dari banyak sampah di luar TPS hingga di selokan pada kawasan jalan rajawali. Serta yang dilakukan instansi terkait pada pengawasan terhadap pengelolaan sampah masih minim karena terdapat banyak sampah di TPS yang sempat terlihat dibiarkan penuh atau menumpuk pada siang hingga malam hari disebabkan angkutan sampah yang kurang serta tidak beraturan waktu antara pembuangan sampah dari masyarakat sama angkutan yang bertugas dalam pengelolaan sampah, banyak sampah dipinggiran jalan maupun di selokan dekat TPS yang masih berserakan tanpa adanya penanganan secara khusus dari instansi tersebut ataupun diawasi pada pengelolaan sampah tersebut.

Ini merupakan masalah yang belum terselesaikan hingga saat ini pada pengawasan yang dilakukan Dinas Pasar dan Kebersihan Kota Palangka Raya. Berdasarkan penjelasan inilah, maka penulis mengangkat judul :PENGAWASAN PEMERINTAH KOTA TERHADAP PENGELOLAAN SAMPAH KOTA PALANGKA RAYA (Studi Di Jalan Rajawali Kel Bukit Tunggal Kec Jekan Raya Kota Palangka Raya). 


\section{METODE PENELITIAN}

Sesuai dengan judul penelitian, penelitian ini menggunakan metode kualitatif, artinya penelitian akan melihat gejala yang terjadi di masyarakat dan memaparkan seperti apa adanya tanpa diikuti persepsi peneliti. Dalam melihat gejala yang terjadi, peneliti berusaha untuk tidak terlibat secara emosional. Penelitian Kualitatif menurut Moleong (2007:6) adalah penelitian yang bermaksud untuk memahami fenomena tentang apa yang dialami oleh subjek peneliti secara holistik (utuh) dan dengan cara deskripsi dalam bentuk kata-kata dan bahasa pada suatu konteks khusus yang alamiah, serta dengan memanfaatkan berbagai metode alamiah yang salah satunya bermanfaat untuk keperluan meneliti dari segi prosesnya.

Lokasi penelitian di Jalan Rajawali Kelurahan Bukit Tunggal Kecamatan Jekan Raya Kota Palangka Raya dalam hal ini dibawah tanggung jawab Dinas Pasar dan Kebersihan Kota Palangka Raya pada Seksi Angkutan Sampah yang berfungsi mengelola sampah dan sekaligus melakukan pengawasan. Alasan memilih penelitian di lokasi tersebut karena wilayah tersebut dalam pengelolaan sampahnya masih terlihat minim.

Sumber data yang diperoleh secara langsung dari sumber asli atau pihak pertama.Data primer secara khusus dikumpulkan oleh peneliti untuk menjawab pertanyaan riset atau penelitian.Data primer dapat berupa pendapat subjek riset (orang) baik secara individu maupun kelompok, hasil observasi terhadap suatu benda (fisik), kejadian, atau kegiatan, dan hasil pengujian.Manfaat utama dari data primer adalah bahwa unsur-unsur kebohongan tertutup terhadap sumber fenomena.Oleh karena itu, data primer lebih mencerminkan kebenaran yang dilihat. Bagaimanapun, untuk memperoleh data primer akan menghabiskan dana yang relatif lebih banyak dan menyita waktu yang relatif lebih lama.

Data sekunder merupakan sumber data yang diperoleh peneliti secara tidak langsung melalui media perantara.Data sekunder pada umumnya berupa bukti, catatan, atau laporan historis yang telah tersusun dalam arsip, baik yang dipublikasikan dan yang tidak dipublikasikan.Manfaat dari data sekunder adalah lebih meminimalkan biaya dan waktu, mengklasifikasikan permasalahan-permasalahan, menciptakan tolak ukur untuk mengevaluasi data primer, dan memenuhi kesenjangan-kesenjangan informasi.Jika informasi telah ada, pengeluaran uang dan pengorbanan waktu dapat dihindari dengan menggunakan data sekunder. Manfaat lain dari data sekunder adalah bahwa seorang peneliti mampu memperoleh informasi lain selain informasi utama.

\section{HASIL DAN DISKUSI}

\section{Bentuk Pengawasan Terhadap Pengelolaan Sampah Di Jalan Rajawali Kel Bukit Tunggal Kec Jekan Raya Kota Palangka Raya}

Dengan mengamati hasil penelitian yang dilakukan melalui wawancara, peneliti langsung mengamati di luar instansi, dan data yang berkaitan dengan pengawasan terhadap pengelolaan sampah di jalan Rajawali Kelurahan Bukit Tunggal Kecamatan Jekan Raya Kota Palangka Raya. Pengawasan secara langsung terhadap petugas angkutan sampah masih ada beberapa kekurangan yaitu pengawas jarang melakukan pengawasan secara langsung karena secara umum pengawasan memiliki 3 (tiga) jenis ialah pengawasan awal, pengawasan proses, dan pengawasan akhir, dan pengawas lapangan belum bertindak secara refresif dengan penerapan tindakan tegas yang berupa pemberian sanksi terhadap masyarakat yang melanggar aturan jam buang sampah yang terdapat pada Peraturan Daerah Kota Palangka Raya Nomor 3 Tahun 2006 Tentang kebersihan Lingkungan Dan Pertamanan serta belum melakukan pengawasan secara khusus pada jalur atau rute yang rawan dipenuhi sampah di luar dari TPS.

Pada angkutan sampah saat awal bekerja hingga selesai bekerja, pengawas lapangan yang peneliti amati mengawasi dalam hal kehadiran petugas yaitu secara absen tertulisdan 
mengawasi hasil kerja angkutan sampah. Pada dasarnya jenis-jenis pengawasan ialah pengawasan awal, pengawasan proses dan pengawasan akhir. Dari hasil pengamatan peneliti di lapangan pengawas lapangan kurang melakukan pengawasan terhadap awal pelaksanaan angkutan sampah di jalan Rajawali serta pada proses angkutan sampah juga kurang diawasi oleh petugas yang berwenang untuk mengawasi kinerja angkutan sampah terlihat pada hasil dokumentasi dan dari hasil wawancara kepada salah satu armada. Pada pelaksanaan kerja yang dilakukan oleh petugas angkutan sampah masih belum maksimal karena bisa dilihat dari sampah yang masih banyak di TPS dan di luar TPS yang tidak terangkut dan jam angkut sampah yang tidak menentu dengan waktu yang telah ditetapkan berdasarkan hasil wawancara kepada masyarakat sekitar TPS dan hasil pengamatan yang peneliti lakukan pada tiap TPS. Serta pengawasan yang dilakukan terhadap masyarakat yang melanggar aturan jam buang sampah dan membuang sampah di luar TPS belum diawasi dengan maksimal oleh pengawas bisa dilihat di TPS yang volume sampah tersebut melebihi dari kapasitas tiap TPS yang telah disediakan kemudian masyarakat masih dengan bebas membuang sampah sembarangan. Tindakan pengawasan berupa penerapan tindakan tegas yang merupakan dari bagian pengawasan belum dilakukan pengawas. Karena tindakan tegasakan memberikan efek jera terhadap masyarakat dan akan menciptakan lingkungan yang bersih bebas dari sampah karena ada efek jera bagi masyarakat dan juga menumbuhkan kesadaran masyarakat akan pentingnya lingkungan yang bersih atau bebas dari sampah.

Berdasarkan fokus penelitian yang meneliti pengawasan yang dilakukan terhadap pengelolaan sampah dengan menggunakan prinsip-prinsip pengawasan masih belum bisa dilaksanakan secara maksimal oleh pengawas pada Kasi Angkutan Sampah penyebab hal demikian, yakni :

1. Pada prinsip tercapainya tujuan ialah control harus ditunjukan terhadap tercapainya tujuan yaitu dengan mengadakan koreksi untuk menghindari penyimpangan-penyimpangan dari pada perencanaan.

Dari hasil penelitian koreksi dilakukan dengan mengadakan evaluasi untuk menyelesaikan masalah yang di hadapi oleh angkutan sampah dengan memberikan pemecahan suatu masalah yang dihadapi. Namun, tujuan dari pengawasan ialah tercipta lingkungan yang bersih melalui peningkatan kinerja armada angkutan sampah dan penerapan tindakan tegas yang memberi efek jera bagi masyarakat yang membuang sampah dengan sembarangan masih belum diterapkan yang menjadi masalah utama kebersihan karena kurangnya kesadaran masyarakat. Karena itu apa yang menjadi tujuan dari pengawasan belum dapat tercapai dengan maksimal.

2. Pada Prinsip Efisiensi Pengawasan ialah control adalah efficient bilamana dapat menghindarkan penyimpangan-penyimpangan dari pada planning, sehingga tidak timbul hal-hal lain di luar dugaan.

Jadi, berdasarkan hasil penelitian pengawasan terhadap pengelolaan sampah yang dilakukan oleh Koordinator Lapangan dan Pengawas Lapangan sudah efisien karena pengawas menghindari penyimpangan-penyimpangan atau kedisiplinan petugas angkutan sampah dengan cara mengabsen petugas lapangan dan meninjau kembali hasil kinerja angkutan sampah pada TPS setelah menerima laporan dari angkutan sampah bahwa sampah di TPS sudah diangkut dan bekerja sama dengan masyarakat setempat untuk turut mengawasi TPS dan pengawas siap menerima komplain dari masyarakat ketika ada sampah di TPS yang belum terangkut dari jadwal angkutan sampah. Namun, penelitian yang berdasarkan hasil wawancara kepada warga yang tinggal dikawasan jalan Rajawali Kelurahan Bukit Tunggal Kecamatan Jekan Raya Kota Palangka Raya bahwa angkutan sampah yang mengangkut di TPS terkadang tidak menentu dari jam angkutan yang ditetapkan dan pada data yang peneliti peroleh. 
3. Pengawasan langsung, dari hasil penelitian yang dilakukan terhadap angkutan sampah yang mengangkut sampah di TPS. Berdasarkan hasil penelitian peneliti menemukan pengawas jarang melakukan pengawasan secara langsung sesuai dengan jenis pengawasan ialah pengawasan awal, proses, dan akhir dilakukan terhadap kinerja angkutan sampah yang bekerja dari pukul 03.00-08.00 dan masyarakat yang membuang sampah di luar dari jam yang telah ditentukan yaitu jam 16.00-03.00 sesuai jam yang ditentukan pada Peraturan Daerah Kota Palangka Raya Nomor 3 Tahun 2006 Tentang Kebersihan Lingkungan Dan Pertamanan.

4. Pada prinsip pengawasan yaitu prinsip standar. Standar yang telah ditetapkan instansi masih belum tercapai dengan maksimal seperti yang telah di ungkapkan oleh Koordinator Lapangan pada Kasi Angkutan Sampah. Penyebab hal tersebut ialah masih banyak masyarakat yang membuang sampah ke TPS tidak sesuai dari jam buang sampah yang telah di tentukan.

5. Pada prinsip daya-suai pengawasan ialah control harus flexible untuk menghindari kegagalan planning.

Dari hasil penelitian pengawasan yang dilakukan sudah flexible karena pengawas meninjau langsung di luar dari waktu yang sudah ditentukan ketika angkutan sampah sudah selesai melaksanakan tugas dan ketika terjadimasalah diluar planning seperti sampah belum terangkut maka pengawas langsung menyelesaikan masalah sampah yang masih belum terangkut di TPS tersebut dengan menghubungi armada angkutan sampah.

6. Pada prinsip peninjauan kembali ialah control adalah sistem control harus ditinjau secara berkali-kali, agar supaya sistem yang digunakan berguna untuk mencapai tujuan. Pada prinsip ini sudah dilakukan oleh pengawas lapangan yang berdasarkan hasil wawancara kepada pengawas lapangan.

Jadi, berdasarkan hasil penelitian di lapangan yang mengamati tiap TPS dan kinerja para petugas angkutan sampah bahwa, penulis menemukan prinsip-prinsip dari pengawasan belum dilaksanakan dengan sepenuhnya mengingat masih terdapat kendala-kendala yang dihadapi dalam pengawasan terhadap pengelolaan sampah seperti masih rendahnya kesadaran masyarakat akan pentingnya kebersihan, kekurangan armada dalam angkutan sampah maupun pengawas lapangan sehingga pengawas lapangan terlihat jarang melakukan pengawasan secara langsung pada petugas angkutan sampah ketika awal angkutan sampah melaksanakan tugasnya hingga petugas angkutan sampah sedang melaksanakan tugas yaitu mengangkut sampah di TPS yang sudah menumpuk dan sampah dari masyarakat berada diluar TPS. Hal demikian juga terdapat pada absen manual yang pada jam pengabsenan oleh pengawas lapangan kepada angkutan sampah tersebut juga tidak ditentukan. Jadi, absen yang dipegang oleh pengawas lapangan untuk jam pengabsenan tidak ditentukan tergantung dari pengawas lapangan kapan mereka mengawasi angkutan sampah tersebut.

\section{Faktor Pendukung Pengawasan}

1. Bentuk pengawasan dengan laporan atau absen manualsehingga ada kedisiplinan dari para petugas angkutan sampah dalam hal kehadiran. Agar pengawas mengetahui kehadiran para petugas angkutan sampah sehingga apa yang diharapkan pengawasan ialah tercipta lingkungan yang bersih atau bebas dari sampah akan terwujud lewat kedisplinan kehadiran dari petugas angkutan sampah. Absen tersebutdilakukan 2 (dua) kali oleh pengawas lapangan, Absen saat kehadiran kerja dilapangan atau absen harian dan laporan retase di TPA dalam artian petugas pengawas mencatat setiap truk masuk.Untuk pengawas sendiri berupa absen pengawas yang dilakukan pada saat upacara atau apel pagi.

2. Adanya peninjauan kembali oleh pengawas lapangan guna mengetahui hasil kinerja dari petugas angkutan sampah apakah sudah sesuai dengan standar yang telah ditetapkan atau 
masih belum mencapai standar tersebut telah dilakukan pengawas agar tujuan dari pengawasan akan tercapai.

3. Koreksi yang dilakukan oleh Kepala Bidang Kebersihan, Koordinator Lapangan, dan Pengawas Lapangan saat upacara atau apel pagi untuk mendapatkan solusi dari permasalahan dalam pengelolaan sampah.

4. Pemberian surat peringatan maupun sanksi terhadap angkutan sampah yang melanggar aturan yang ditetapkan oleh Bidang Kebersihan untuk mencegah terjadi kembali pelanggaran yang dilakukan petugas angkutan sampah sehingga angkutan sampah bekerja sesuai intruksi yang diberikandengan melakukan tindakan tegas terhadap angkutan sampah yang melanggar peraturan. Tindakan pengawas yang dilakukan kepada petugas angkutan sampah yang melanggar peraturan petugas angkutan terbagi menjadi 2 (dua), yakni petugas angkutan sampah yang sebagai PNS dan tenaga kontrak ketika tenaga PNS melanggar akan diberikan surat peringatan 1 (satu) hingga ke 3 (tiga) bagi yang melanggar melebihi itu maka, akan dikenakan sanksi sesuai dengan pelanggaran yang dilakukan. Kemudian untuk tenaga PNS akan diserahkan pada Bidang Kepegawaian dan kepada tenaga kontrak maka akan diberhentikan sesuai dengan perjanjian kontrak. Tindakan yang dilakukan guna mendisiplinkan petugas angkutan sampah sehingga petugas angkutan sampah tidak melanggar intruksi yang diberikan dan adanya peningkatan kinerja angkutan sampah.

5. Peran masyarakat dalam pengawasan sehingga ketika ada sampah yang belum diangkut di TPS maka, masyarakat melaporkan kepada Kepala Bidang Kebersihan maupun Pengawas Lapangan setelah itu Pengawas Lapangan menghubungi Sopir Armada dan melakukan pengangkutan sampah pada TPS yang telah dilaporkan masyarakat ke instansi.

\section{Faktor Penghambat Pengawasan}

1. Jumlah pengawas lapangan yang masih kurang atau tidak seimbang dengan jumlah armada menyebabkan pengawasan yang dilakukan kurang berjalan dengan efektif sesuai dengan data yang peneliti peroleh dalam jumlah pengawas lapangan tidak sebanding dengan jumlah armada angkutan sampah yang pada setiap armada maupun truk armada angkutan sampah ada pengawas lapangan dari awal berangkat armada ke TPS hingga selesai pekerjaan petugas angkutan sampah melaksanakan tugas mengangkut sampah di TPS. Guna meningkatkan kinerja para armada sehingga sampah yang di TPS bisa terangkut dengan maksimal dan adanya pengawasan terhadap masyarakat yang membuang sampah di TPS serta pemulung yang memungut sampah di TPS agar sampah sisa yang di ambil pemulung tidak berhamburan di luar TPS.

2. Absen yang bersifat tertulis sehingga akan memberikan celah untuk melakukan pelanggaran yang dilakukan petugas angkutan sampah dan dari teknis pelaksanaan absen tersebut juga tidak menentu sesuai dari hasil wawancara kepada pengawas lapangan.

3. Peran serta masyarakat dalam pengelolaan sampah masih belum maksimal terlihat ketika masih banyak sampah pada TPS di jalan Rajawali yang belum terangkut. Yang kemudianpeneliti temukan disebabkan oleh masih rendah kesadaran dari masyarakat akan kebersihan lingkungan seperti jam buang sampah tidak beraturan dilakukan oleh masyarakat. Jam buang yang seharusnnya 16.00-03.00 sesuai dalam Peraturan Daerah Kota Palangka Raya Nomor 3 Tahun 2006 Tentang Kebersihan Lingkungan dan Pertamanan pada Pasal 7 ayat 6, yakni : Membuang sampah pada TPS mulai pukul 16.00 WIB sampai dengan pukul 03.00 WIB. Hal demikian masih dilanggar oleh masyarakat dan kemudian angkutan sampah mengangkut dari jam 03.00-08.00 WIB. Jam buang sampah dari masyarakat belum bisa diawasi sehingga masih terihat bahwa pengawas kurang melakukan pengawasan pada daerah rawan yang sampah tersebut selalu menumpuk hingga di luar TPS karena jam buang sampah tidak beraturan. 
4. Sarana TPS yang kurang memadai karena dari hasil pengamatan peneliti ada beberapa TPS yang belum terawat dan TPS tersebut sudah tidak mampu menampung banyaknya volume sampah dari masyarakat yang semakin meningkat. Selain itu, dilihat dari segi monitoring terhadap TPS masih kurang diperhatikan sehingga perawatan TPS kurang dilakukan karena bisa dilihat dari kondisi beberapa TPS di kawasan jalan Rajawali yang belum diperbaiki.

\section{KESIMPULAN}

Berdasarkan penelitian yang dilakukan dengan terdapat beberapa temuan peneliti di lapangan serta dari analisis yang telah dilakukan peneliti, maka peneliti memberikan kesimpulan sebagai berikut :

\section{Bentuk Pengawasan Pengelolaan Sampah}

Bentuk pengawasan berdasarkan hasil penelitian dapat ditarik kesimpulan bahwa bentuk pengawasan terhadap pengelolaan sampah bersifat absen serta pengawasan yang dilakukan masih belum maksimal dikarenakan jumlah personil pengawas lapangan belum sebanding dengan jumlah armada angkutan sampah. Selain itu, berdasarkan hasil penelitian yang dilakukan peneliti pada pengawasan terhadap pengelolaan sampah di jalan Rajawali Kelurahan Bukit Tunggal Kecamatan Jekan Raya Kota Palangka Raya. Kemudian sesuai dengan fokus penelitian ialah meneliti berdasarkan prinsip-prinsip pengawasan masih belum tercapai dengan maksimal, yakni : Pada prinsip pengawasan langsung belum bisa dilaksanakan dengan maksimal oleh pengawas karena berdasarkan data yang peneliti peroleh jumlah pengawas lapangan tidak sebanding dengan jumlah armada angkutan sampah. Pada prinsip tercapainya tujuan belum bisa tercapai dengan maksimal karena partisipasi masyarakat dalam pengelolaan sampah masih sangat minim. Berdasarkan hasil penelitian, peneliti menyatakan bahwa pada prinsip standart yang ditetapkan oleh pengawas yaitu belum bisa tercapai karena pengawasan terhadap masyarakat masih minim terlihat bahwa tindakan tegas dari pengawas ketika melihat masyarakat dengan sengaja membuang sampah sembarangan hanya memberikan nasehat atau belum ada penerapan sanksi atau tindakan-tindakan tegas tersebut bagi masyarakat.

\section{Faktor Pendukung}

Faktor pendukung pengawasan terhadap pengelolaan sampah ialah bentuk dari pengawasan dengan melakukan absen manual kepada petugas pengawas dan petugas angkutan sampah untuk mengetahui kehadiran dari petugas pengawas dan angkutan sampah atau mendisiplinkan petugas tersebut dengan melakukan tindakan tegas terhadap petugas angkutan sampah yang melanggar tata tertib. Serta ada peninjauan kembali yang dilakukan pengawas lapangan setelah angkutan sampah selesai mengangkut sampah pada tiap TPS sesuai waktu dan jalur yang ditentukan maka pengawas mengetahui keadaan setiap TPS ditambah pengawasan yang dilakukan juga bekerja sama dengan masyarakat setempat untuk mengetahui keadaan TPS apakah sampah yang berada pada TPS sudah diangkut atau belum.

\section{Faktor Penghambat}

Kemudian faktor penghambat berdasarkan hasil penelitian. Faktor tersebut tidak terlepas dari ketersediaan sumber daya manusia (SDM) dalam mengawasi pengelolaan sampah. Keterbatasan SDM mempengaruhi dari kinerja pengawasan terhadap pengelolaan sampah yang dilakukan pemerintah kota lewat Dinas Pasar dan Kebersihan Kota Palangka Raya. Kekurangan SDM menjadi penyebab masih terdapat kekurangan dalam pengawasan serta partisipasi masyarakat terhadap pengelolaan sampah masih rendah karena kesadaran masyarakat akan menjaga kebersihan lingkungan masih belum terlihat dengan maksimal 
dan absen yang masih dilakukan secara tertulis sehingga masih ada celah untuk melakukan pelanggaran dalam kehadiran petugas angkutan sampah.

\section{SARAN}

Saran yang diberikan dari peneliti melihat dari hasil penelitian pada pengawasan terhadap pengelolaan sampah. Peneliti memberikan saran sebagai berikut:

\section{Kepada Pemerintah Kota :}

a) Anggaran khusus untuk pengawasan lebih diperhatikan karena menjadi hal yang lebih diperhatikan juga karena dari hasil penelitian. Peneliti menemukan terdapat kekurangan jumlah pengawas lapangan karena dengan jumlah pengawas lapangan yang kurang pengawasan pada kinerja dari para petugas angkutan sampah masih belum bisa dilakukan dengan maksimal.

b) Melakukan penambahan terhadap jumlah armada angkutan sampah karena jumlah armada yang tersedia saat ini masih belum bisa mengangkut sampah dengan maksimal hal tersebut diakibatkan oleh pertumbuhan jumlah penduduk dan tingkat konsumsi masyarakat menghasilkan volume sampah yang terus bertambah setiap saat.

c) Pemerintah kota dapat membentuk suatu organisasi kreatif masyarakat yang terdiri dari masyarakat untuk mengajak masyarakat lain melalui keluarga dan kerabat untuk ikut masuk dalam organisasi tersebut yang bertujuan untuk mengelola sampah menjadi barang yang berharga dan sampah bukan menjadi masalah lagi melainkan sampah dapat menjadi penghasilan bagi masyarakat untuk pertumbuhan ekonomi dan peningkatan Pendapatan Asli Daerah (PAD) Kota Palangka Raya kemudian masyarakat bisa mengawasi lebih optimal pada kebersihan lingkungan mereka.

\section{Kepada Dinas Pasar dan Kebersihan Kota Palangka Raya}

Melakukan penerapkan tindakan tegas yang dilakukan pengawas berdasarkan Peraturan Daerah Kota Palangka Raya Nomor 3 Tahun 2006 Tentang Kebersihan Lingkungan Dan Pertamanan dan Undang-Undang Nomor 18 Tahun 2008 Tentang Pengelolaan Sampah. Karena dengan pemberian nasehat kepada masyarakat yang melanggar dinilai masih belum efektif dan masyarakat masih saja suka melanggar aturan tersebut. Maka dari itu, peneliti memberikan saran agar ada penerapan sanksi atau tindakan tegas yang memberikan efek jera sehingga dapat menumbuhkan kesadaran masyarakat akan pentingnya menjaga kebersihan lingkungan dapat tercapai. Kemudian memberikan absen dengan menggunakan sidik jari bagi para petugas angkutan sampah guna menghindari terjadinya pelanggaran pada kehadiran petugas tersebut.

\section{Kepada Kasi Angkutan Sampah}

Kepada Kasi Angkutan Sampah yang bertugas mengelola sampah dan melakukan pengawasan terhadap pengelolaan sampah khusus pada jalan Rajawali Kelurahan Bukit Tunggal Kecamatan Jekan Raya Kota Palangka Raya agar dapat meningkatkan pengawasan yang dilakukan kepada angkutan sampah dan masyarakat karena dari temuan peneliti di lapangan kinerja angkutan sampah masih belum maksimal karena angkutan sampah belum maksimal mengangkut sampah di TPS ketika kapasitas truk angkutan sampah masih bisa menampung sampah serta pengawas lapangan belum secara maksimal dapat mengawasi kinerja angkutan sampah dari awal angkutan sampah bekerja hingga akhir angkutan sampah bekerja sehingga kinerja angkutan sampah dapat berjalan dengan lebih baik lagi, dan untuk masyarakat yang membuang sampah tidak pada TPS hendaknya diberi pengawasan lebih lagi dengan melakukan tindakan tegas mengingat kesadaran masyarakat tersebut masih rendah. 
Melihat hal demikian perlu ada tindakan dari pemerintah secara khusus di jalur yang rawan atau masih terdapat banyak sampah yang mengotori jalur tersebut. Pengawasan yang dilakukan oleh pemerintah lewat instansi terkait masih belum menunjukkan bahwa pengawasan yang dilakukan sudah maksimal karena banyak sampah yang berserakan serta belum melakukan tindakan-tindakan tegas bagi yang melanggar aturan tentang membuang sampah.

\section{Kepada masyarakat}

Untuk masyarakat kiranya dapat lebih ikut berpartisipasi pada pengawasan terhadap pengelolaan sampah untuk peningkatan kinerja dari pemerintah kota dalam menanggulangi masalah sampah serta masyarakat lain yang membuang sampah sembarangan dan memungut sampah di TPS yang bisa menyebabkan sampah berserakan di luar TPS. Masyarakat juga hendaknya melakukan kegiatan kebersihan lingkungan dengan bergotong royong melakukan kerja bakti bersama-sama membersihkan lokasi yang dipenuhi dengan sampah khususnya pada wilayah tempat tinggal mereka. Mengingat kondisi lingkungan yang kotor dapat menjadi sarang penyakit bagi masyarakat itu sendiri seperti penyakit demam berdarah, muntaber, penyakit kulit dan penyakit lainnya.

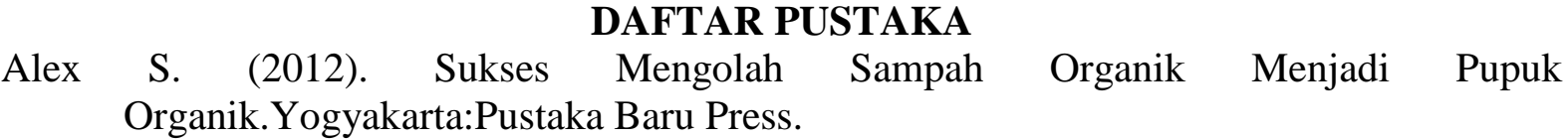

Bungin, Burhan. (2007). Penelitian Kualitatif : Komunikasi, Ekonomi, Kebijakan Publik, dan Ilmu Sosial Lainnya. Kencana. Jakarta: Prenada Media Group.

Daniel, Valerina. (2009). Easy Green Living.Hikmah. Bandung.

Ernie dan Saefullah, 2005. Dasar-Dasar Manajemen.Bandung: CV Mandar Maju.

G.R Terry, 1986. Principles of Managemen: Dasar-Dasar Manajemen. Bandung:CV Mandar Maju.

Henri Fayol, 1992.Dasar-Dasar Manajemen.Bandung: CV Mandar Maju.

Hrold Koontz dan Cyril O'Donnell. Principles of Management: Dasar-Dasar Manajemen. Bandung: CV Mandar Maju.

http://accounting-media.com/2014/06/data-primer-dan-data sekunder.html (diakses tanggal 14 januari 2015).

http://adieprahartanto.com/2012/08/kumpulan-variabel-dimensi-danindikator_28.html(diakses tanggal 29 januari 2015).

http://detikkalbar.com/penanganan-sampah-di-kota-palangka-raya-perlu-sinergitas/. (Diakses tanggal 6 Januari 2015).

http://farelbae.wordpress.com/catatan-kuliah-ku/pengertian-pengumpulan-data/ (diakses tanggal 23 oktober 2014).

http://kaltengpos.web.id/berita/detail/15075/2015-masalah-sampah-hantui-palangkaraya.html. (diakses tangal 10 Februari 2015).

http://sigerus.com/2014/03/sosialisasi-pemanfaatan-sampah-melalui.html (diakses tanggal 24 januari2015).

http://www.academia.edu/4422523/BAB_III_METODE_PENELITIAN_3.

_Lokasi_Penelitian. (diakses tanggal 23 oktober 2014). 
http://www.slideshare.net/metrosanita/undangundang-no-18-tahun-2008-tentangpengelolaansampah. (diakses tanggal 7 desember 2014).

http://www.slideshare.net/NastitiChristianto/teknik-analisis-data-kuantitatif-dan-kualitatif. (diakses tanggal 23 oktober 2014).

https://iskandarlbs.files.wordpress.com/2010/11/miles-huberman-buku.doc.(diakses tanggal 29 januari 2015).

Intruksi Presiden Republik Indonesia Nomor 15 Tahun 1983 Tentang Pedoman Pelaksanaan Pengawasan.

Laporan Tahunan Kelurahan Bukit Tunggal 2013.

Pedoman Penulisan Skripsi Jurusan Ilmu Pemerintahan Fakultas Ilmu Sosial dan Ilmu Politik

Peraturan Daerah Kota Palangka Raya Nomor 3 Tahun 2006 Tentang Kebersihan Lingkungan dan Pertamanan.

Peraturan Walikota Palangka Raya Nomor 51 Tahun 2012 Uraian Tugas Jabatan Struktural Di Lingkungan Pasar Dan Kebersihan Kota Palangka Raya.

Profil Dinas Pasar dan Kebersihan Kota Palangka Raya.

Rosidi, Abidarin. (2013). Reinventing Government. Yogyakarta: CV Andi.

SALINDEHO, Jhon. (1995). Pengawasan Melekat.Jakarta: Bumi Aksara.

Sukarna.(1992:112). Dasar-Dasar Manajemen. Bandung:CV Mandar Maju.

Undang-Undang Nomor 18 Tahun 2008 Tentang Pengelolaan Sampah.

Wintoko, Bambang. (2010). Panduan Praktis Mendirikan Bank Sampah. Yogyakarta: Pustaka Baru Press. 